\title{
Effect of Caffeine on Thyroid and Pituitary Function in Newborn Rats ${ }^{(40)}$
}

\author{
MARTINE CLOZEL, CHARLOTTE L. BRANCHAUD, \\ GLORIA S. TANNENBAUM, JEAN H. DUSSAULT, AND JACOB V. ARANDA ${ }^{(41)}$ \\ Developmental Pharmacology and Perinatal Research Unit, Department of Endocrinology, McGill University- \\ Montreal Children's Hospital Research Institute, Montreal, Quebec, Canada and Department of Endocrinology,
}

Universite Laval, Quebec City, Quebec, Canada

\begin{abstract}
Summary
The possibility that caffeine, a central nervous system stimulant used in neonatal apnea, may produce acute or chronic changes in growth hormone (GH), thyroxine $\left(\mathrm{T}_{4}\right)$ and thyrotropin (TSH) was studied in the newborn rat. Five-day-old rats were separated into three groups: control (0) group receiving saline, Group I (low dose caffeine) receiving $5 \mathrm{mg} / \mathrm{kg}$ and Group II (high dose caffeine) receiving $50 \mathrm{mg} / \mathrm{kg}$. Acute effects were studied at 2, 4, and $24 \mathrm{~h}$ after injection. Chronic effects were studied $24 \mathrm{~h}$ after the last of 10 daily injections. $\mathrm{GH}, \mathrm{T}_{4}$, and $\mathrm{TSH}$ were measured by radioimmunoassay and caffeine by high pressure liquid chromatograph. GH was increased at all times and all doses after a single injection of caffeine. After chronic therapy, the increase in GH was small, suggesting depletion of pituitary reserve. A high dose of caffeine had a biphasic effect on $T_{4}$ with an increase at $4 \mathrm{~h}$ and a decrease at 24 h. Thyrotropin-releasing hormone (TRH)-induced TSH release at $24 \mathrm{~h}$ was not influenced by caffeine administration. Chronic caffeine therapy stimulated both $\mathbf{T}_{4}$ and TSH; however, TRH-stimulated TSH release was decreased, suggesting that chronic therapy may blunt pituitary TSH response.
\end{abstract}

Abbreviations

GH, growth hormone

PDE, phosphodiesterase

$T_{3}$, triiodothyronine

$\mathbf{T}_{4}$, thyroxine

TRH, thyrotropin releasing hormone

TSH, thyrotropin

Besides the stimulant effect of the methylxanthines on the central nervous system and on cardiac inotropy and chronotropy, these compounds exert a variety of hormonal and metabolic effects. The administration of two methylxanthines, caffeine and theophylline, to adult rats results in decreased $\mathrm{GH}, \mathrm{TSH}, \mathrm{T}_{3}$ and thyroxine $\mathrm{T}_{4}$ serum levels (29). But in in vitro isolated organ preparations, caffeine increases $\mathrm{T}_{4}(3)$ and $\mathrm{TSH}(28)$ release, and theophylline increases the release of GH (32). Published data on the hormonal effects of methylxanthines in humans are contradictory. Peracchi et al. (25) and Ensinck et al. (17) observed a decrease in $\mathrm{GH}$ level in acromegalic patients after aminophylline. In normal men, Blackard et al. (8) and Peracchi et al. (25) did not find any modification in basal $\mathrm{GH}$ after aminophylline, whereas, Ensinck et al. (17) described a decrease in GH serum level. After a low dose of oral caffeine given to adult healthy men, neither GH, TSH nor $\mathrm{T}_{3}$ were modified (30). Because caffeine is currently used in the premature neonate for the treatment of apnea, we evaluated the changes in $\mathrm{GH}, \mathrm{T}_{4}$, and $\mathrm{TSH}$ after caffeine in the newborn rat.

\section{MATERIALS AND METHODS}

Five-day-old male Sprague-Dawley rats were obtained from the Canadian Breeding Farm, St. Constant, Quebec. Two sets of experiments were respectively designed to evaluate the acute and the chronic effects of caffeine. Each set used three groups: a control group, which received saline; a low dose caffeine group, which received $5 \mathrm{mg} / \mathrm{kg}$ of caffeine dissolved in saline; and a high dose caffeine group, which received $50 \mathrm{mg} / \mathrm{kg}$. Caffeine (37) or saline was injected intraperitoneally in a volume of $0.05 \mathrm{ml} /$ rat. Each group consisted of $30-35$ rats. In the acute experiment, the animals were sacrificed at various time intervals after a single injection of saline or caffeine: 2,4 , and $24 \mathrm{~h}$. In the chronic experiment, animals were injected daily for a 10 day period. They were sacrificed $24 \mathrm{~h}$ after the last injection. The rat pups were kept with their suckling mothers throughout the experiments and maintained on a $12 \mathrm{~h}$ light-dark cycle.

At the end of the $24 \mathrm{~h}$ experiment, several rats $(n=6)$ of the control group and of the low dose caffeine group received TRH, in order to evaluate the effect of caffeine on TRH-induced TSH release. In the chronic experiment, each of the three groups was divided into two: for the measurement of either basal TSH $(n=$ 20 ) or TRH-stimulated TSH $(n=10)$. Rats receiving TRH (38) were injected intraperitoneally with $100 \mathrm{ng}$ TRH/100 g body weight, $15 \mathrm{~min}$ before sacrifice, as described by Walker et al. (34). TRH was dissolved in saline. The volume of TRH in saline was $0.05 \mathrm{ml} / 10 \mathrm{~g}$ of body weight given intraperitoneally.

At the termination of all studies, animals were sacrificed by rapid decapitation at the same time of the day, between 14:00 and 14:30. Blood was collected, and plasma or serum obtained was stored at $-20^{\circ} \mathrm{C}$ until subsequent analysis. $\mathrm{T}_{4}$ and $\mathrm{GH}$ were measured in plasma, TSH in serum. $\mathrm{T}_{4}$ was measured using an Amerlex $T_{4}$ radioimmunoassay kit (Amersham Corporation), TSH (34) and GH (33) by double antibody radioimmunoassay with materials supplied by the NIADDK (39). The TSH intraassay variation is $6-8 \%$; interassay variation is $12 \%$ and the sensitivity was between $10-15 \mathrm{ng}$ per tube. For the GH assay, the intra- and interassay coefficients of variation determined for a sample mean of $25 \mathrm{ng} / \mathrm{ml}$ were 8.9 and 7.2 , respectively. The minimum detectable concentration in the radioimmunoassay defined as the concentration of rat $\mathrm{GH}$, which resulted in a binding of $\left[{ }^{125} \mathrm{I}\right]$ or $\mathrm{GH}$ to antiserum that was 2 standard deviations below the mean binding achieved in the absence of $\mathrm{GH}$, was $3.1 \mathrm{ng} / \mathrm{ml}$.

Caffeine and one of its potential metabolites, theophylline, were measured by high pressure liquid chromatography (2). The sensitivity of the caffeine assay was $0.1 \mathrm{mg} /$ liter and the coefficient of variance at $10 \mathrm{mg} / \mathrm{liter}$ was $4.0 \%$.

Statistical analysis was performed using two-way analysis of variance (36) or unpaired Student's $t$ test. All values are reported as mean \pm S.E.

\section{RESULTS}

$G H$. Figure 1 shows the effects of caffeine on plasma GH levels in the short term experiment. There was a trend to an increase in plasma GH levels in response to both doses of caffeine at all time points examined. The effect increased significantly with the dose. After chronic treatment (Fig. 2) a significant increase $(P<0.05)$ 


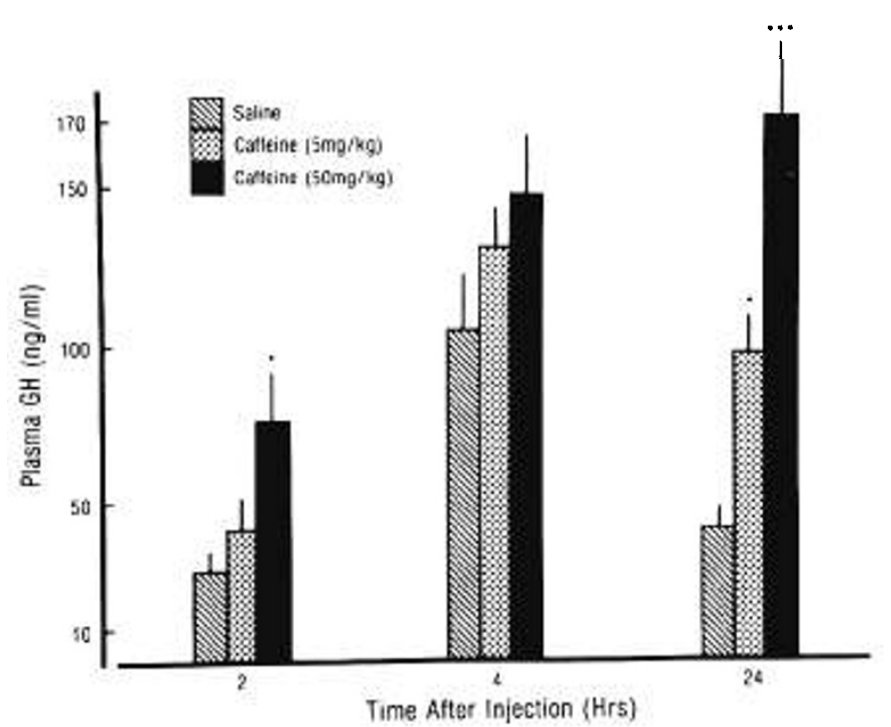

Fig. 1. Effect of a single administration of saline $(n=10)$, caffeine 5 $\mathrm{mg} / \mathrm{kg}(n=10)$, and caffeine $50 \mathrm{mg} / \mathrm{kg}(n=9)$ on growth hormone (GH) plasma levels (mean \pm S.E.) at different times after injection. ${ }^{*} P<0.05$ and ${ }^{* * *} P<0.001$, compared to the control group (saline).

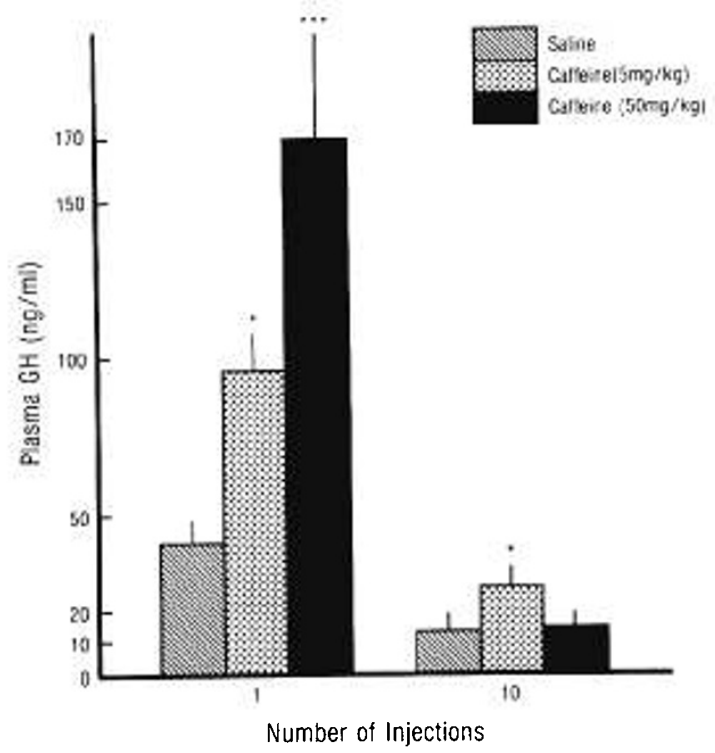

Fig. 2. Effect of saline, caffeine $5 \mathrm{mg} / \mathrm{kg}$, and caffeine $50 \mathrm{mg} / \mathrm{kg}$, on growth hormone $(\mathrm{GH})$ plasma levels (mean \pm S.E.) $24 \mathrm{~h}$ after a single injection (left $)$ and $24 \mathrm{~h}$ after 10 days of treatment (right) $(n=14) .{ }^{*} P<$ 0.05 and ${ }^{* * *} P<0.001$, compared to the control group (saline).

in plasma GH levels was noted only after a low dose of caffeine $(5 \mathrm{mg} / \mathrm{kg})$; thus, the effect of chronic treatment was attenuated when compared to the effect of a single injection of caffeine.

Pituitary-thyroid axis. Figure 3 illustrates the acute effects of caffeine on plasma $T_{4}$. No significant change was noted at $2 \mathrm{~h}$. At $4 \mathrm{~h}$, a high dose of caffeine significantly increased the level of plasma $\mathrm{T}_{4}(3.79 \pm 0.13$ versus $3.28 \pm 0.15 \mu \mathrm{g} / \mathrm{dl}, \cdot P<0.05)$. In contrast, at $24 \mathrm{~h}$, a high dose decreased significantly the level of plasma $\mathrm{T}_{4}(4.05 \pm 0.18$ versus $4.81 \pm 0.19 \mu \mathrm{g} / \mathrm{dl}, P<0.001)$. To confirm this unexpected biphasic effect, the $24 \mathrm{~h}$ experiment was repeated in 4-day-old rats instead of 5-day-old animals, so that the rats were sacrificed at the same age as the rats from the 2 and $4 \mathrm{~h}$ experiments. A decrease in plasma $T_{4}$ concentration after 5 $\mathrm{mg} / \mathrm{kg}$ of caffeine $(1.35 \pm 0.11$ versus $1.97 \pm 0.20 \mu \mathrm{g} / \mathrm{dl}, P<0.01)$ was noted. To determine whether this decrease in $T_{4}$ level was a direct effect of caffeine on the thyroid gland, or was due to an inhibition of TSH secretion, TRH-induced TSH release was meas- ured $24 \mathrm{~h}$ after either saline (control group) or $50 \mathrm{mg} / \mathrm{kg}$ of caffeine (treated group) in the 4-day-old rats. No significant change in TRH-stimulated TSH was noted $(377.8 \pm 32.5$ versus $360.7 \pm 37 \mu \mathrm{g} / 100 \mathrm{ml}$ ).

Table 1 shows the effect of chronic caffeine treatment on basal and TRH-stimulated $\mathrm{T}_{4}$ and on basal and TRH-stimulated TSH. Both low and high doses of caffeine significantly $(P<0.001)$ increased $\mathrm{T}_{4}$ levels $(5.06 \pm 0.29$ and $6.04 \pm 0.22$, respectively, versus $4.12 \pm 0.27 \mu \mathrm{g} / \mathrm{dl}$ in 0 dose). The same pattern was found after TRH administration but there was no significant difference in each group between basal $\mathrm{T}_{4}$ and TRH-stimulated $\mathrm{T}_{4}$, suggesting that the $15 \mathrm{~min}$ interval between TRH administration and sacrifice was probably too short to produce changes in $T_{4}$ concentration. Chronic therapy with caffeine resulted in $\mathrm{T}_{4}$ levels greater then control animals (Table 1), suggesting an escape phenomenon from the biphasic effect obtained with acute caffeine administration.

Basal TSH was slightly increased by a low dose $(17.9 \pm 2.57$ versus $10.6 \pm 1.43 \mu \mathrm{g} / \mathrm{dl})$ and significantly by a high dose of caffeine $(25.1 \pm 6.93$ versus $10.6 \pm 1.43 \mu \mathrm{g} / \mathrm{dl}, P<0.05)$ (Table 1$)$. The TSH levels after TRH stimulation was considerably greater than basal levels $(216.6 \pm 45.5$ versus $10.6 \pm 1.4 \mu \mathrm{g} / 100 \mathrm{ml})$; however, chronic caffeine therapy with both low $(5 \mathrm{mg} / \mathrm{kg})$ and high doses $(50 \mathrm{mg} / \mathrm{kg})$ attenuated the TSH response to TRH stimulation. In the caffeine-treated rats, the TSH levels in the TRH-stimulated rats were much higher than the basal TSH. But TSH levels after TRH stimulation in the low and high caffeinetreated rats were significantly lower compared to the non-caffeine treated group (Table 1), suggesting that chronic caffeine therapy may possibly lead to exhaustion of pituitary reserve.

Caffeine assay. The plasma levels of caffeine and of theophylline obtained after injection of caffeine are shown in Table 2 . The peak plasma concentration of caffeine after $5 \mathrm{mg} / \mathrm{kg}$ is $5.26 \pm 0.38$ $\mathrm{mg} /$ liter, which is within the lower therapeutic range for the management of neonatal apnea. After $50 \mathrm{mg} / \mathrm{kg}$, the peak concentration is $67.57 \pm 2.84 \mathrm{mg} / \mathrm{liter}$, which is supra-therapeutic concentration.

The caffeine level $24 \mathrm{~h}$ after the last injection of a chronic treatment with $50 \mathrm{mg} / \mathrm{kg}(2.00 \pm 1.26 \mathrm{mg} / \mathrm{liter})$ is much lower than $24 \mathrm{~h}$ after a single injection of $50 \mathrm{mg} / \mathrm{kg}(20.65 \pm 3.36 \mathrm{mg} /$ liter), suggesting that there is no accumulation of the drug and/or that the clearance is greater at 15 days of age than at 5 days. No demethylation of caffeine into theophylline was detected after a single injection of $5 \mathrm{mg} / \mathrm{kg}$.

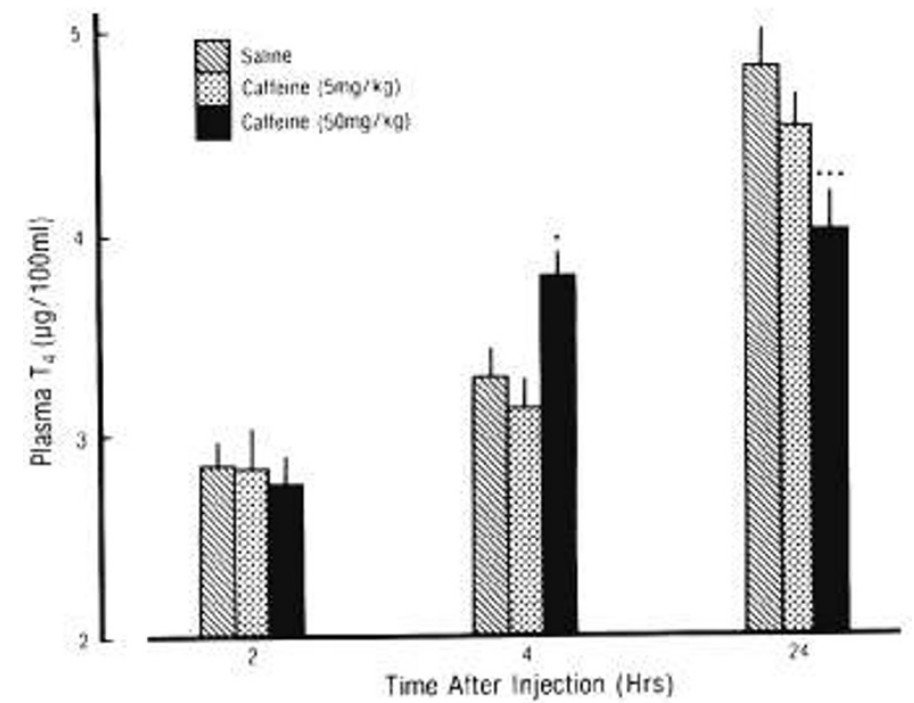

Fig. 3. Effect of a single administration of saline, cafteine $\supset \mathrm{mg} / \mathrm{kg}$, and caffeine $50 \mathrm{mg} / \mathrm{kg}$, on thyroxine $\left(\mathrm{T}_{4}\right)$ plasma levels (mean \pm S.E.) at different times after injection. ${ }^{*} P<0.05$ and ${ }^{* * *} P<0.01$, compared to the control group (saline). 
Table I. Effect of chronic treatment by caffeine on basal $T_{4}$, thyrotropin releasing hormone-(TRH)-stimulated $T_{4}$, basal TSH, TRHstimulated TSH (data are expressed as means \pm S.E.M.)

\begin{tabular}{|c|c|c|c|c|}
\hline \multirow{2}{*}{$\begin{array}{c}\text { Caffeine } \\
\text { (mg/kg/day) } \\
\text { (for } 10 \text { days) }\end{array}$} & \multicolumn{2}{|c|}{$\mathrm{T}_{4}(\mu \mathrm{s} / 100 \mathrm{ml})$} & \multicolumn{2}{|c|}{$\mathrm{TSH}(\mu \mathrm{g} / 100 \mathrm{ml})$} \\
\hline & Basal & TRH-stimulated & Basal & TRH-stimulated \\
\hline 0 & $4.12 \pm 0.27$ & $4.73 \pm 0.44$ & $10.6 \pm 1.4$ & $216.6 \pm 45.5$ \\
\hline 5 & $5.06 \pm 0.29^{1}$ & $5.47 \pm 0.32^{2}$ & $17.9 \pm 2.6$ & $101.9 \pm 19.5^{3}$ \\
\hline 50 & $6.04 \pm 0.22^{1}$ & $6.66 \pm 1.53^{2}$ & $25.1 \pm 6.9^{3}$ & $153.6 \pm 31.7^{3}$ \\
\hline
\end{tabular}

${ }^{1} P<0.001$ compared to 0 caffeine dose

${ }^{2} P<0.01$ compared to 0 caffeine dose.

${ }^{3} P<0.05$ compared to 0 caffeine dose.

\section{DISCUSSION}

GH. The wide fluctuations in individual concentrations of plasma GH noted by several investigators (23) may explain the discrepancies we found between the control groups in the acute experiments. In the adult male rat, GH secretion is characterized by an endogenous ultradian rhythm with a period of $3.3 \mathrm{~h}$ with synchronization of the pulses between animals (33). In the newborn rat, GH is high (21), and follows an episodic secretion pattern, which is more erratic than that of adult rats (16) with no synchronization of the pulses between animals. Therefore, the time of the sacrifice may have occurred at various points of the $\mathrm{GH}$ secretory pattern in individual rats.

At the end of the chronic experiment, i.e., at 15 days of age, the control GH values were lower than in the acute experiments. This decrease parallels the physiologic pattern of plasma GH level in the developing rat. GH level is high in cord blood and during the first days of life, then decreases until 26 days of age (16).

Our study shows a consistent positive effect of caffeine on GH plasma levels in the newborn rat. A blunted response after a chronic treatment relative to a single injection suggests a possible exhaustion of the pituitary gland due to prolonged stimulation by caffeine. The lower plasma caffeine level after 10 days of treatment, compared to $24 \mathrm{~h}$ after a single injection, may also be responsible for this smaller effect.

Several mechanisms may explain caffeine stimulation of GH secretion. Methylxanthines are PDE inhibitors, leading to an increase in pituitary cyclic AMP which is involved in GH release (32). The concentrations of caffeine or theophylline required for PDE inhibition are much greater than the therapeutic range. An effect of caffeine on neurotransmitters is also possible. Caffeine has been shown to increase the turnover of norepinephrine (7) and of serotonin (6) in the brain. Both norepinephrine and serotin stimulate GH secretion (23) in adult rats and humans. Similarly, in the newborn rat, serotonin increases $\mathrm{GH}$ release. But the alphaadrenergic component of $\mathrm{GH}$ stimulation is inactive in the neonate (21), suggesting that norepinephrine-mediated GH stimulation is an unlikely mechanism in this age group.

Significant clinical laboratory changes may be expected from these hormonal effects. When used in the newborn infant for the treatment of apnea, caffeine may induce an increase in blood glucose $(22)$ as does theophylline $(4,31)$, another methylxanthine that can be methylated into caffeine in the newborn (9). It is possible that caffeine-induced increase in GH may play a role in the elevation of blood glucose; however, exogenous GH has been reported to fail to induce major metabolic changes in early infancy (14). Conversely, hyperglycemia has been shown to have a paradoxical positive effect on GH secretion in the newborn infant up to 10 days of life (10), and might participate in the increase in $\mathrm{GH}$ after caffeine. The significant increase in $\mathrm{GH}$ after chronic administration of a therapeutic dose of caffeine might possibly be of clinical importance. Available data, however, show no difference in growth and development between caffeine-treated premature infants and matched control infants in long term follow-up studies (20).

Pituitary-thyroid axis. Our studies show that an acute single dose of caffeine alters $\mathrm{T}_{4}$ and TSH. The significant decrease in plasma $\mathrm{T}_{4}$ noted $24 \mathrm{~h}$ after one injection of caffeine is not due to the comparison with a high control level because this decrease was reproducible when saline or caffeine was given at 4 days of age where the control group had a low $\mathrm{T}_{4}$ level. This high level in the control group is probably due to increasing age because those rats were sacrificed at 6 days of age. The increase in basal $T_{4}$ level between 5 and 6 days is in agreement with the increase found by Walker in the developing rat between 5 and 7 days (35). The decrease in plasma $T_{4}$ concentration at $24 \mathrm{~h}$ is unlikely to be due to an inhibition of TSH secretion by caffeine because TRHstimulated TSH is not significantly different with or without caffeine. It may be due either to an increased peripheral metabolism of $T_{4}$ into $T_{3}$ and/or to a direct inhibition of $T_{4}$ secretion by caffeine. The biphasic effect of $50 \mathrm{mg} / \mathrm{kg}$ of caffeine on $\mathrm{T}_{4}$ level is in accord with the in vitro experiment of Amiragova (3) on isolated thyroid tissue, wherein caffeine increased $\mathrm{T}_{4}$ secretion but decreased $\mathrm{T}_{4}$ synthesis.

Chronic stimulation of $\mathrm{T}_{4}$ and TSH release is demonstrated after caffeine. The parallelism of the dose-response curves suggests that caffeine increases chronic $T_{4}$ secretion by increasing TSH pituitary release. TRH-stimulated TSH release is attenuated by caffeine, suggesting that long-term stimulation by caffeine may blunt the capacity of the pituitary thyrotroph cells to respond to TRH. It may be due to a chronic increase in TSH release with or without inhibition of TSH synthesis after caffeine. This is in accord with the absence of reactivity of TSH to TRH in the few cases of pituitary TSH secreting tumors reported (5). Although our results suggest an effect of caffeine at the pituitary level, a stimulatory effect on the hypothalamus cannot be excluded because we did not measure TRH.

Thyroid hormones play an important role in GH synthesis and secretion in the newborn rat as well as in the adult rat (11). The administration of $T_{3}$ results in restoration of the depleted pituitary GH content in neonatal hypothyroid rats, but $T_{3}$ induced hyperthyroidism decreases pituitary GH content in previously normal rats. One of the possible explanations would be an "increased fractional removal rate for intrapituitary GH" (11), that would lead to increased plasma GH concentrations. The thyroid stimulation after chronic caffeine therapy might add to the positive effect of caffeine on plasma $\mathrm{GH}$ level.

Whether caffeine has the same effects on $\mathrm{T}_{4}$ and $\mathrm{TSH}$ in the newborn infant as in the newborn rat remains to be investigated.

Table 2. Plasma concentration of caffeine and theophylline as a function of dose and age

\begin{tabular}{|c|c|c|c|c|c|c|}
\hline \multirow{2}{*}{$\begin{array}{l}\text { Age } \\
\text { (day) }\end{array}$} & \multirow{2}{*}{$\begin{array}{c}\text { Time } \\
\text { (h) }\end{array}$} & \multirow[b]{2}{*}{$n$} & \multicolumn{2}{|c|}{ Caffeine (mg/liter) } & \multicolumn{2}{|c|}{$\begin{array}{c}\text { Theophylline (mg/ } \\
\text { liter) }\end{array}$} \\
\hline & & & $5^{1}$ & $50^{1}$ & $5^{1}$ & $50^{1}$ \\
\hline \multirow[t]{3}{*}{5} & 2 & 10 & $3.34 \pm 0.49$ & $67.57 \pm 2.84$ & $\mathrm{ND}^{2}$ & $\mathrm{ND}^{2}$ \\
\hline & 4 & 10 & $5.26 \pm 0.38$ & $59.99 \pm 2.34$ & $\mathrm{ND}^{2}$ & $0.93 \pm 0.11$ \\
\hline & 24 & 10 & $1.52 \pm 0.09$ & $29.65 \pm 3.36$ & $\mathrm{ND}^{2}$ & $1.99 \pm 0.09$ \\
\hline 15 & 24 & 6 & $\mathrm{ND}^{2}$ & $2.00 \pm 1.26$ & $\begin{array}{c}0.64 \pm \\
0.07\end{array}$ & $2.75 \pm 0.58$ \\
\hline
\end{tabular}

${ }^{1}$ Dose of caffeine $(\mathrm{mg} / \mathrm{kg})$.

${ }^{2} \mathrm{ND}$, Non-detectable. Lower limit of sensitivity $=0.5 \mathrm{mg} / \mathrm{liter}$. 
The rat is born with an immature hormonal state and the maturation of the pituitary-thyroid axis proceeds during the first 2 wk of postnatal life $(13,15)$. In contrast, this maturational process begins at mid-gestation in the human fetus. Thyroid responsiveness to TSH and TSH responsiveness to exogenous TRH are high at birth in the human neonate (18) relative to the rat (27). In the preterm infant, $T_{3}$ and $T_{4}$ are lower than in the full term infant throughout the first weeks of life $(1,12)$. Even lower $T_{3}$ and $T_{4}$ levels have been found in premature babies with respiratory distress syndrome $(1,26)$. Increasing a previously low $T_{4}$ plasma level might be one of the mechanisms by which caffeine or theophylline increase the metabolic rate in the newborn $(19,24)$.

\section{REFERENCES AND NOTES}

1. Abbassi, V., Merchant, K., and Abramson, D: Postnatal triiodothyronine concentrations in healthy preterm infants and in infants with Respiratory Distres Syndrome. Pediatr. Res. 11: 802, (1977).

2. Aldridge, A., Aranda, J. V., and Neims, A. H.: Caffeine metabolism in the newborn. Clin. Pharmacol. Ther. 25: 447 (1979)

3. Amiragova, M. G.: The effect of caffeine and barbamyl on the secretory cycle of the thyroid gland. Biull. Eksp. Biol. Med., 54: 54, (1962).

4. Aranda, J. V., and Dupont, C.: Metabolic effects of theophylline in the premature neonate. J. Pediatr., 89: 833 (1976).

5. Benoit, R., Pearson-Murphy, B. E., Robert, F., Marcovitz, S., Hardy, J., Tsoukas, G., and Gardiner, R. J.: Hyperthyroidism due to a pituitary TSH secreting tumor with amenorrhoeagalatorrhoea. Clin. Endocrinol., 12: 11 (1980)

6. Berkowitz, B. A. and Spector, S.,: The effect of caffeine and theophylline on the disposition of brain serotonin in the rat. Eur. J. Pharmacol., 16: 322 (1971).

7. Berkowitz, B. A., Tarver, J. H., and Spector, S., Release of norpinephrine in the central nervous system by theophylline and caffeine. Eur. J. Pharmacol., 10: 64 (1970)

8. Blackard, W. G. and Heidingsfelder, S. A.,: Adrenergic receptor control mechanism for growth hormone secretion. J Clin. Invest., 47: 1407 (1968).

9. Bory, C., Baltassat, P., Porthault, M., Bethenod, M., Frederich, A., and Aranda, J. V.,: Metabolism of theophylline to caffeine in premature newborn infants. J. Pediatr. 94: 988 (1979).

10. Cornblath, M., Parker, M. L., Reisner, S. H., Forbes, A. E., and Daughaday, W $H_{\text {.,: }}$ Secretion and metabolism of growth hormone in premature and full-term infants. J. Clin. Endocrinol., 25: 209 (1965).

11. Coulombe, P., Ruel, J., and Dussault, J. H.: Effects of neonatal hypo- and hyperthyroidism on pituitary growth hormone content in the rat. Endocrinology, 107: 2027 (1980)

12. Cuestas, R. A.: Thyroid function in healthy premature infants. J. Pediatr., 92 963 (I978).

13. Dubois, J. D. and Dussault, J. H.,: Ontogenesis of thyroid function in the neonatal rat. Thyroxine $\left(\mathrm{T}_{4}\right)$ and triiodothyronine $\left(\mathrm{T}_{3}\right)$ production rates. Endocrinology, 101: 435 (1977).

14. Ducharme, J. R. and Grumbach, M. M.,: Studies on the effects of human growth hormone in premature infants. J. Clin. Invest, 40: 243 (1961).

15. Dussault, J. H. and Labrie, F.: Development of the hypo-thalamic-pituitarythyroid axis in the neonatal rat. Endocrinology, 97: 1321 (1975).

16. Eden, S., Albertsson-Wikland, K., and Isaksson, O.: Plasma levels of growth hormone in female rats of different ages. Acta Endocrinol., 88676 (1978).

17. Ensinck, J. W., Stoll, R. W., Gale, C. C., Santen, R. J., Touber, J. L., and Williams, R. H.: Effect of aminophylline on the secretion of insulin, glucagon, luteinizing hormone and growth hormone in humans. J. Clin. Endocrinol., 31: $153(1970)$.

18. Fisher, D. A. and Klein, A. H.: Thyroid development and disorders of thyroid function in the newborn. N. Engl. J. Med., 304: 702 (1981).
19. Gerhardt, T., McCarthy, J., and Bancalari, E.: Effect of aminophylline on respiratory center activity and metabolic rate in premature infants with idiopathic apnea. Pediatrics, 63: 537 (1979).

20. Gunn, T. R., Metrakos, K., Riley, P., Willis, D., and Aranda, J. V.: Sequelae of caffeine treatment in preterm infants with apnea. J. Pediatr., 94: 106 (1979).

21. Kuhn, C. M. and Schanberg, S. M.: Maturation of central nervous system control of growth hormone secretion in rats. J. Pharmacol. Exp. Ther., 217: 152 (1981).

22. Lazaro-Lopez, F, Colle, E., Dupont, C., and Aranda, J. V.: Metabolic effects of caffeine in the preterm neonate. Pediatr. Res. (Abstract), 14: 468 (1980).

23. Martin, J. B., Brazeau, P., Tannenbaum, G. S., Willoughby, J. O., Epelbaum, J., Terry, L. C., and Durand, D.: Neuroendocrine organization of growth hormone regulation. In: S. Reichlin, R. J. Baldessarini, J. B. Marton (Eds). The Hypothalamus. pp 329-357. (Raven Press, New York, 1978).

24. Milsap, R. L., Krauss, A. N., Auld, P. A. M.: Oxygen consumption in apneic premature infants after low dose theophylline. Clin. Pharmacol. Ther., 28: 536 (1980).

25. Peracchi, M., Cavagnini, F., Pontiroli, A. E., Rassi, U., Malinverni, A., and Pinto, M.: Effect of aminophylline on growth hormone secretion in man. Acta Endocrinol., 76: 488 (1974).

26. Redding, R. A. and Pereira, C.: Thyroid function in respiratory distress syndrome (RDS) of the newborn. Pediatrics, 54: 423 (1974).

27. Simpkins, J. W., Bruni, J. F., Midouszewski, R. J., and Meites, J.: Serum and pituitary TSH and response to TRH in developing male and female rats. Endocrinology, 98: 1365 (1976).

28. Skelbelskaja, J. B.: The effects of caffeine on the reaction of the thyroid gland to "stress." Probl. Endokr. Gormonoter, 6: 7 (1960).

29. Spindel, E., Arnold, M., Cusack, B., and Wurtman, R. J.: Effects of caffeine on anterior pituitary and thyroid function in the rat. J. Pharmacol. Exp. Ther., 214: 58 (1980).

30. Spindel, E. R., McCall, A. J., and Wurtman, R. J.: Lack of endocrine effects of a low dose of caffeine in man. Third International Caffeine Committee Workshop, October 27, 28 1980. Hunt Valley, Maryland.

31. Srinivasan, G., Pildes, R. S., Jaspan, J. B., Singh, J., Shankar, H., Yeh, T. F., and Tiruvury, A.: Metabolic effects of theophylline in preterm infants. J. Pediatr, 98: $815(1981)$

32. Steiner, A. L., Peake, G. T., Utiger, R., and Kipnis, D.: Median eminence stimulation of growth hormone (GH) and thyrotropin (TSH) secretion and the pituitary adenyl cyclase system. J. Clin. Invest. (Abstract), 48: 80a (1969).

33. Tannenbaum, G. S. and Martin, J. B.: Evidence for an endogenous ultradian rhythm governing growth hormone secretion in the rat. Endocrinology, 98: 562 (1976).

34. Walker, P., Coulombe, P., and Dussault, J. H.: Effects of triiodothyronine on thyrotropin-releasing hormone-induced thyrotropin release in the neonatal rat Endocrinology, 107: 1731 (1980).

35. Walker, P., Dubois, J. D., and Dussault, J. R.: Free thyroid hormone concentrations during postnatal development in the rat. Pediatr. Res., 14: 247 (1980).

36. Winer, B. J.: Statistical principles in experimental design. New York, McGrawHill, 1971 .

37. Sigma Chemical Co., St. Louis, MO

38. Winer, B. J.: Statistical principles in experimental design. New York, McGrawHill, 1971.

37. Sigma Chemical Co., St. Louis, MO

38. Hoechst Canada, Inc., Montreal, Canada

39. Bethesda, Maryland.

40. Supported by grants from the Medical Research Council of Canada and a research fellowship from the McGill University-Montreal Children's Hospital Research Institute. This is publication number 82039 of the McGill UniversityMontreal Children's Hospital Research Institute

41. Address for reprints: Dr. Jacob V. Aranda, McGill University-Montreal Children's Hospital, Research Institute, 2300 Tupper Avenue, Montreal, Quebec Canada, $\mathrm{H} 3 \mathrm{H} 1 \mathrm{P} 3$.

42. Received for publication March 8, 1982

43. Accepted for publication November 10, 1982. 